\title{
PENGARUH JANGKAUAN PASAR, SKALA PRODUKSI DAN PANJANG SALURAN PEMASARAN TERHADAP PREFERENSI PETANI UNTUK MEMILIKI SERTIFIKASI ORGANIK
}

\author{
Novita $^{1}$, Fahrul Riza ${ }^{2}$ \\ ${ }^{1)}$ Program Studi Manajemen, Universitas Bunda Mulia \\ ${ }^{2)}$ Program Studi Manajemen, Universitas Bunda Mulia
}

\begin{abstract}
Indonesia is one of the Ten Countries with Largest Organic Area 2012 in Asia. Permentan No. 64 tahun 2013 on organic certification aims to make organic farmers protected in their organic activities. But the fact is, the number of uncertified organic farmers in Indonesia is still high at 48\%. The purpose of this research is to know the influence of market concentration, scale of production and length of product chain to preference by using logistic regression model. Respondents in this study are 100 organic producers that have uncertified organic land.
\end{abstract}

Keywords: organic certification, preference, market concentration, scale of production, length of product chain

\begin{abstract}
ABSTRAK
Indonesia merupakan salah satu negara yang masuk dalam The Ten Countries with the Largest Organic Area 2012 di kawasan Asia. Pemerintah telah memberlakukan Permentan No. 64 tahun 2013 yang bertujuan agar para petani organik lebih terlindungi dalam mengembangkan kegiatan organiknya. Tetapi faktanya, sekarang ini jumlah petani organik yang tidak tersertifikasi di Indonesia masih tinggi yaitu sebesar $48 \%$. Tujuan penelitian ini adalah mengetahui pengaruh jangkauan pasar, skala produksi dan panjang saluran distribusi terhadap preferensi memiliki sertifikasi organik dengan menggunakan model logistic regression. Responden dalam penelitian ini adalah 100 produsen organik yang memiliki lahan organik tidak tersertifikasi.
\end{abstract}

Kata kunci : sertifikasi organik, preferensi, jangkauan pasar, skala produksi panjang saluran pemasaran

\section{PENDAHULUAN}

Pola pertanian organik semakin mendominasi wacana bidang pertanian dewasa ini. Berdasarkan data yang diperoleh dari IFOAM, pasar produk organik dunia tumbuh hingga US\$ 5 miliar/tahun. Nilai ekspor produk organik dari ASEAN mencapai US\$ 65 miliar pada 2012 dan diestimasi menembus US\$ 70 miliar pada tahun 2013 (http://industri.bisnis.com/read/20140619/99/ 237376/pertanian-organik-prospek-pasartumbuh-hingga-us5-miliartahun).

Di negara-negara maju, tingkat pertumbuhan produk organik sangat tinggi yakni mencapai lebih dari $20 \%$ setiap tahunnya (Sulaeman, 2014). Gaya hidup sehat dengan slogan "Back to Nature"telah menjadi tren baru yang mendunia, meninggalkan pola hidup lama yang menggunakan bahan kimia non alami, seperti pupuk, pestisida kimia sintetis dan hormon tumbuh dalam produksi pertanian. Pangan yang sehat dan bergizi tinggi dapat diproduksi dengan metode baru yang dikenal dengan pertanian organik (Truong et al., 2012).

Dikutip dari Peraturan Menteri Pertanian Nomor 64/Permentan/OT.140/5/2013, pertanian organik merupakan teknik budidaya pertanian yang mengandalkan pada bahan-bahan alami tanpa menggunakan bahan-bahan kimia sintetis. Tujuan utama pertanian organik adalah menyediakan bahan pangan yang aman bagi kesehatan produsen dan konsumennya serta tidak merusak lingkungan (Badgley et al., 2007).

Pertanian organik di Indonesia memiliki potensi yang cukup besar untuk dapat bersaing di pasar internasional walaupun 
secara bertahap. Potensi tersebut tercermin dari berbagai keunggulan yang dimiliki, antara lain 1) lahan untuk pertanian organik masih cukup luas; 2) teknologi untuk mendukung pertanian organik sudah cukup tersedia, seperti pembuatan kompos, tanam tanpa olah tanah, pestisida hayati dan praktik lainnya. Dengan memanfaatkan berbagai keunggulan tersebut, pertanian organik di Indonesia dapat diprioritaskan untuk memenuhi kebutuhan pasar domestik dan ekspor (Khudori, 2014).

Indonesia merupakan salah satu negara yang masuk dalam The Ten Countries with the Largest Organic Area 2012 di kawasan Asia. Untuk memasuki pasar dunia, produk pertanian organik di Indonesia harus memiliki standar yang disesuaikan dengan ketentuan negara tujuan ekspor. Yang menjadi tantangan bagi produk pertanian organik di Indonesia adalah masalah standarisasi. Harus diakui bahwa standarisasi produk organik di Indonesia belum bisa diterima di masyarakat Eropa. Salah satu cara yang dapat dilakukan untuk memenuhi ketentuan standarisasi organik adalah dengan sertifikasi organik (Gerrard et al., 2013).

Sertifikasi organik merupakan cerminan kualitas produk organik (Larceneux et al, 2012). Pemerintah Indonesia melalui Departemen Pertanian sangat mendukung program peningkatan daya saing produk organik di Indonesia melalui Peraturan Menteri Pertanian No. 64 tahun 2013. Permentan tersebut mengatur bahwa setiap unit usaha yang mengklaim produknya organik, harus melalui proses sertifikasi oleh LSO yang telah terakreditasi oleh KAN dan telah terdaftar di OKPO. Apabila ada unit usaha yang mengklaim produknya organik tanpa melalui proses sertifikasi, akan mendapatkan sanksi sesuai dengan peraturan perundangan yang berlaku yaitu Peraturan Menteri Pertanian Nomor 64/Permentan/OT.140/5/2013. Permentan ini mulai disahkan pada 29 Mei 2013 dan diberlakukan pada Mei 2014. Tujuannya agar para petani organik lebih terlindungi dalam mengembangkan kegiatan organiknya. Dengan aturan yang jelas dan didukung oleh kepercayaan konsumen terhadap produk organik yang beredar, diharapkan dapat meningkatkan jumlah petani yang bersertifikat organik. Tetapi faktanya, jumlah petani organik yang tidak tersertifikasi di Indonesia masih tinggi (Statistik Pertanian Organik Indonesia, 2014).

Tingginya jumlah petani organik yang tidak tersertifikasi tersebut disebabkan oleh proses sertifikasi organik yang dianggap mahal dan rumit. Biaya sertifikasi yang berkisar antara Rp. 7.500.000,- sampai dengan Rp. 15.000.000,- per tahun dianggap mahal oleh sebagian besar petani. Prosedur sertifikasi berupa sistem pendokumentasian tertulis juga banyak dikeluhkan oleh para petani organik. Hal ini terkait erat dengan budaya Indonesia yang lebih ke budaya tutur daripada budaya tulis. Ditambah lagi dengan kenyataan bahwa sebagian besar petani organik di Indonesia (terutama yang berusia lanjut) masih buta huruf.

Di Indonesia, petani organik yang tersertifikasi pada umumnya memiliki kriteria sebagai berikut 1) produk pertanian yang dihasilkan utamanya dijual untuk pasar internasional atau ekspor (meski tidak tertutup kemungkinan produk tersebut juga dijual di pasar domestik atau nasional); 2) memiliki skala lahan dan/atau volume produksi yang tergolong besar (angka tepatnya tergantung dari jenis komoditas yang diusahakan); 3) konsumen yang membeli produk pertanian berada jauh (secara geografis) dari lokasi produsen, sehingga untuk mencapai konsumen akhir dibutuhkan perantara perdagangan (Sertifikasi Organis Komunitas, 2013).

Merujuk pada penelitian-penelitian yang telah dilakukan sebelumnya, kebanyakan peneliti hanya meneliti pada proses pertanian organiknya saja. Namun penelitian tentang sertifikasi produk organik masih sangat jarang dilakukan. Padahal proses pertanian organik yang bagus tanpa disertai dengan jaminan kualitas organik berupa sertifikasi, 
membuat produk pertanian organik sulit bersaing di pasar domestik maupun internasional. Oleh karena itu, penelitian ini akan mengangkat tema tentang bagaimana preferensi petani organik di Indonesia untuk memiliki sertifikasi organik.

Perumusan masalah dalam penelitian ini sebagai berikut :

1. Apakah jangkauan pasar (market concentration) berpengaruh terhadap preferensi petani untuk memiliki sertifikasi organik?

2. Apakah skala produksi (scale of production) berpengaruh terhadap preferensi petani untuk memiliki sertifikasi organik?

3. Apakah panjang saluran pemasaran (length of product chain) berpengaruh terhadap preferensi petani untuk memiliki sertifikasi organik?

\section{TINJAUAN PUSTAKA}

\section{Sistem Pertanian Organik}

Sistem pertanian organik adalah sistem manajemen produksi yang holistik untuk meningkatkan dan mengembangkan kesehatan agroekosistem, termasuk keragaman hayati, siklus biologi dan aktivitas biologi tanah (Peraturan Menteri Pertanian Nomor 64/Permentan/OT.140/5/2013).

\section{Produk Pertanian Organik}

Produk pertanian organik atau pangan organik dapat diidentikkan sebagai pangan yang dihasilkan dengan cara yang unik (Radman, 2005). Seyfang (2007) menyatakan bahwa pangan organik dan pangan nonorganik berbeda berdasarkan metode produksinya. Pangan organik menggunakan metode penanaman yang bebas pestisida, tidak menggunakan zat penumbuh tanaman dan tidak menggunakan rekayasa genetik.Pangan organik dipercaya lebih menyehatkan dan aman dibandingkan dengan pangan non-organik karena dianggap lebih ramah lingkungan (Paul and Rana, 2012). Konsumen yang peduli terhadap kerusakan lingkungan, bersedia membayar lebih mahal untuk membeli pangan organik (Tarkiainen and Sundqvist, 2005).

\section{Potensi Produk Pertanian Organik}

Konsumen membeli produk pertanian organik didasarkan pada alasan bahwa pangan organik memiliki kualitas yang tinggi, menyehatkan, lebih bernutrisi, aman dikonsumsi, ramah lingkungan, tidak cepat busuk dan memiliki rasa yang lebih enak dibandingkan dengan pangan non-organik (Truong et al, 2012; Paul and Rana, 2012; Chen, 2009; Klockner and Ohms, 2009; Essoussi and Zahaf, 2008).

Indonesia merupakan salah satu penghasil kopi organik berkualitas ekspor. Kopi organik yang dihasilkan oleh Kelompok Tani Kopi Arabika di daerah Gayo, Kabupaten Aceh Tengah telah memperoleh akreditasi dari Bio-coffee IFOAM dan memperoleh label ECO dari negeri Belanda. Gabungan Kelompok Tani Simpatik Tasikmalaya dibantu oleh Sunria telah mengekspor beras organik pandanwangi, beras organik volcano dan beras organik hutan hujan di pasar internasional. Beras organik volcano telah memenangkan penghargaan bergengsi di Amerika Serikat, yaitu SOFI Silver Award untuk kategori Outstanding USDA-Organic Product.

(http://sp.beritasatu.com/home/beras-organiktasikmalaya-tembus-pasarinternasional/79256)

\section{Potensi Pasar Produk Pertanian Organik}

Di negara-negara maju, tingkat pertumbuhan pangan organik sangat tinggi yakni mencapai lebih dari $20 \%$ setiap tahunnya. Jerman merupakan pasar pangan organik terbesar di dunia diikuti oleh Perancis dan Inggris di peringkat kedua dan ketiga (Willer and Klicher, 2009). Pada saat ini, satu dari empat orang Amerika 
mengonsumsi pangan organik. Sedangkan di Eropa, diperkirakan satu dari dua orang Jerman mengonsumsi pangan organik (Sulaeman, 2014). Indonesia juga memiliki potensi pasar domestik yang cukup besar. Meskipun ceruk pasar produk organik masih kecil dan terbatas, tetapi adanya perkembangan kelas menengah, pertumbuhan pendapatan, dan meningkatnya kesadaran akan pentingnya aspek kesehatan merupakan pasar baru untuk produk-produk organik (Khudori, 2014).

\section{Sertifikasi Organik}

Sertifikasi merupakan tolok ukur keorganikan produk (Drichoutis et al, 2006). Dengan memiliki jaminan atas integritas organik, maka diharapkan dapat meningkatkan kepercayaan masyarakat sekaligus mendapatkan jaminan atas produk organik tanpa mengakibatkan kerugian bagi konsumennya (Smed et al, 2013). Dari sudut pandang pemasaran, sertifikasi dapat dianggap sebagai "signal of quality". Sertifikasi organik dapat membantu konsumen untuk mengevaluasi kualitas pangan organik secara keseluruhan (Carpenter and Larceneux, 2008; Koos, 2011). Selanjutnya keberadaan sertifikasi dapat merangsang pembelian produk organik (Gerrard et al, 2013; Nelson, 2010).

\section{Pengaruh Jangkauan Pasar Terhadap Preferensi Memiliki Sertifikasi Organik}

Di Indonesia, sertifikasi organik umumnya dimiliki oleh petani atau produsen organik yang produk pertanian organiknya bertujuan untuk dijual ke pasar nasional dan pasar internasional (Sertifikasi Organik Komunitas, 2013). Untuk petani organik dengan jangkauan pasar lokal, konsumen tidak memerlukan sertifikasi untuk menjamin keorganikan produknya. Konsumen lebih suka mengakses ke lahan petani dan melihat proses bertaninya secara langsung. Konsumen jenis ini biasanya telah mengenal petani secara personal, sehingga kepercayaan telah terjalin secara baik (Kardinan, 2014).
Berdasarkan hal tersebut, ditentukan hipotesis penelitian sebagai berikut :

$\mathrm{H}_{1}$ : Jangkauan pasar berpengaruhterhadap preferensi petani untuk memiliki sertifikasi organik.

\section{Pengaruh Skala Produksi Terhadap Preferensi Memiliki Sertifikasi Organik}

Berdasarkan data dari Aliansi Organis Indonesia, petani yang memiliki sertifikasi organik perorangan memiliki skala lahan atau volume produksi yang tergolong besar (angka tepatnya tergantung dari jenis komoditas yang diusahakan). Biaya sertifikasi organik tergolong mahal, yaitu antara $\mathrm{Rp} 7.500 .000$,sampai dengan $\mathrm{Rp}$ 15.000.000,- tergantung dari jarak antara lokasi lahan petani dengan lokasi LSO. Untuk pertanian organik dengan volume produksi yang besar, biaya sertifikasi tidak akan terlalu berpengaruh terhadap harga produk yang dihasilkan. Tetapi untuk pertanian organik dengan skala produksi yang kecil, biaya sertifikasi akan berpengaruh besar terhadap harga jual produknya. Hal ini dikenal dengan istilah economic of scale (Khudori, 2014). Berdasarkan hal tersebut, ditentukan hipotesis penelitian sebagai berikut :

$\mathrm{H}_{2}$ : Skala produksi berpengaruhterhadap preferensi petani untuk memiliki sertifikasi organik.

\section{Pengaruh Panjang Saluran Pemasaran Terhadap Preferensi Memiliki Sertifikasi Organik}

Pemasaran merupakan salah satu bagian penting yang harus dilakukan oleh petani organik. Petani organik dapat memasarkan produknya melalui dua cara, yaitu menjual langsung kepada konsumen akhir (direct marketing) atau melalui perantara perdagangan. Produk pertanian organik yang tidak tersertifikasi umumnya tidak dapat dipasarkan di jaringan retail besar seperti supermarket. Beberapa petani organik melakukan pemasaran produk melalui penjualan langsung dengan cara transaksi di 
tempat atau diantar sesuai pesanan konsumen. Pemasaran melalui penjualan langsung banyak dilakukan di Jepang. Sejak tahun 1980, petani organik di Jepang menggunakan sanchoku (direct marketing) dimana petani, retailer, restoran dan konsumen saling berhubungan secara langsung dan bekerjasama dalam menentukan keragaman, jumlah dan harga produk (Kimura dan Nishiyama, 2008; Giner, 2009). Dengan metode pemasaran langsung, tidak diperlukan sertifikasi karena konsumen telah percaya bahwa produknya organik (Skulskis and Girgzdiene, 2013). Berdasarkan hal tersebut, ditentukan hipotesis penelitian sebagai berikut :

$\mathrm{H}_{3}$ : Panjang saluran pemasaran berpengaruhterhadap preferensi petani untuk memiliki sertifikasi organik.

\section{Model Penelitian}

Berdasarkan hipotesis diatas, dapat digambarkan menjadi model penelitian sebagai berikut :

\section{Gambar 1. Model Penelitian}

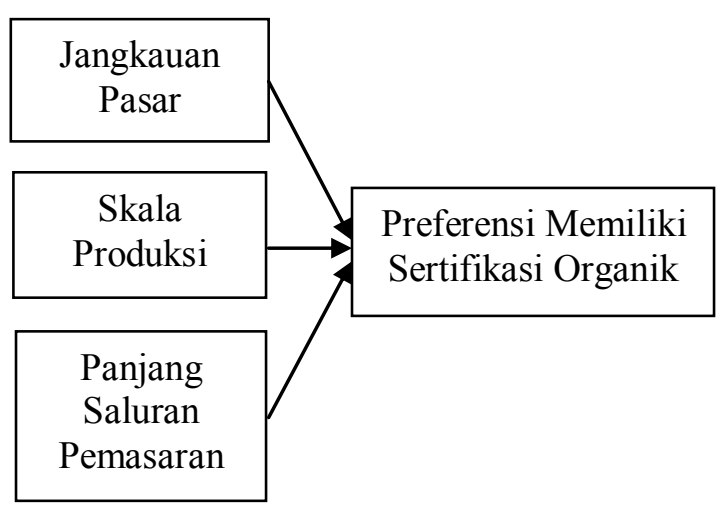

Sumber : peneliti

\section{METODE PENELITIAN}

\section{Pendekatan Penelitian}

Penelitian dilakukan dengan metode kuantitatif yang menekankan analisisnya pada data numerik yang diolah dengan metode statistik. Menurut kedalamannya, penelitian ini termasuk pada penelitian inferensial yang melakukan analisis hubungan antar variabel dengan pengujian hipotesis. Subyek penelitian ini adalah petani organik. Sedangkan obyek penelitian ini adalah preferensi petani untuk memiliki sertifikasi organik.

\section{Populasi dan Sampel}

Populasi dalam penelitian ini adalah petani dan produsen organik di Indonesia yang memiliki lahan pertanian organik yang tidak tersertifikasi. Petani organik adalah pemilik lahan organik yang dalam pengolahannya dikerjakan sendiri. Produsen organik adalah pemilik lahan organik tetapi memilih untuk menggaji buruh tani untuk mengerjakan lahannya. Teknik pengambilan sampel dilakukan dengan caranon probability sampling yaitu dengan convenience sampling. Oleh karena keterbatasan waktu penyebaran kuisioner dan sulitnya mencari responden yang sesuai dengan kriteria populasi, maka sampai dengan waktu yang ditentukan hanya diperoleh 73 
responden.Jumlah ini dianggap sudah cukup, didasarkan pada pendapat Roscoe (1982; Sugiyono, 2015) yang menyatakan bahwa ukuran sampel yang layak dalam penelitian adalah antara 30 sampai dengan 500 .

\section{Data dan Sumber Data}

Teknik pengumpulan data dalam penelitian melalui observasi, wawancara dan kuisioner. Data usaha meliputi nama usaha, lokasiusaha, luas lahan, dan produk pertanian yang dihasilkan. Pengisian kuisioner dilakukan oleh pewawancara berdasarkan jawaban dari responden. Pengisian kusioner oleh pewawancara dilakukan untuk menghindari bias dalam penjawab pertanyaan, karena kemungkinan responden telah melihat seluruh isi pertanyaan dalam kusioner. Selain alasan tersebut, terdapat beberapa petani organik yang buta huruf sehingga cara ini dapat membantu responden dalam pengisian kuisioner. Untuk petani organik yang berada di lokasi yang jauh dari peneliti, peneliti melakukan survei melalui hubungan telepon. Pada responden jenis ini, pengisian kusioner dilakukan oleh peneliti untuk menghemat waktu penelitian.

\section{Variabel Penelitian}

\section{Variabel Terikat}

- Preferensi Memiliki Sertifikasi Organik (Y) adalah ketertarikan responden untuk memiliki sertifikasi organik. Variabel ini diukur dengan menggunakan data binari atau dummy variabel dimana angka 0 adalah tidak tertarik dan 1 adalah tertarik untuk memiliki sertifikasi organik.

\section{Variabel Bebas}

- Jangkauan Pasar $\left(\mathrm{X}_{1}\right)$ adalah luas daerah pemasaran dari produk pertanian organik. Pengukuran menggunakan skala Likert 3 skala dari $1 \mathrm{~s} / \mathrm{d}$ 3, dimana 1 lokal; 2 nasional; 3 internasional.

- Skala Produksi $\left(\mathrm{X}_{2}\right)$ adalah volume produksi pertanian organik dalam sekali masa panen. Pengukuran menggunakan skala Likert 3 skala dari $1 \mathrm{~s} / \mathrm{d} 3$, dimana 1 kecil; 2 menengah; 3 besar.

- Panjang Saluran Pemasaran $\left(\mathrm{X}_{3}\right)$ adalah jarak pemasaran dari petani organik ke konsumen akhir. Variabel ini diukur dengan menggunakan data binari atau dummy variabel dimana angka 0 adalah tanpa perantara perdagangan (direct marketing) dan 1 adalah melalui perantara perdagangan.

\section{Teknik Analisis Data}

Teknik analisis data menggunakan analisis regresi logistik. Teknik ini dapat diandalkan untuk mengukur efek masingmasing variabel, baik untuk variabel dalam data kontinu, kategori maupun biner yang berposisi pada variabel bebas maupun terikat (Wright dikutip dalam Woldeyohanes, 2014). Variabel yang dikotomik/biner adalah variabel yang hanya mempunyai dua kategori saja, yaitu kategori yang menyatakan kejadian sukses $(\mathrm{Y}=1)$ dan kategori yang menyatakan kejadian gagal $(\mathrm{Y}=0)$. Bentuk umum model peluang regresi logistik dengan $\mathrm{p}$ variabel penjelas, diformulasikan sebagai berikut:

$$
\pi(x)=\frac{\exp \left(\beta_{0}+\beta_{1} x_{1}+\ldots \ldots .+\beta_{p} x_{p}\right)}{1+\exp \left(\beta_{0}+\beta_{1} x_{1}+\ldots \ldots+\beta_{p} x_{p}\right)}
$$

dengan $\pi(\mathrm{x})$ adalah peluang kejadian sukses dengan nilai probabilita $0 \leq \pi(\mathrm{x}) \leq 1$ dan $\beta \mathrm{j}$ adalah nilai parameter dengan $j=1,2, \ldots \ldots ., p$. $\pi(\mathrm{x})$ merupakan fungsi yang non linier.

Dalam model penelitian ini, preferensi memiliki sertifikasi organik dianggap hanya dua, yaitu tertarik memiliki sertifikasi organik (1) atau tidak tertarik memiliki sertifikasi organik (0). Dengan model matematika dapat digambarkan sebagai berikut :

$Y=\left\{\frac{1 \text { if } Y *>0}{0 \text { if } Y * \leq 0}\right.$

Dengan menggunakan jawaban kualitatif, peluang $\mathrm{Y}=1$ adalah sama dengan 
kemungkinan seberapa besar peluang latent variabelnya adalah positif. Sehingga dapat dinyatakan dalam model sebagai berikut :

$P\left(Y *>0=P\left(\beta^{\prime} X+\varepsilon>0=P\left(\varepsilon>-\beta^{\prime} X=P\left(\varepsilon<\beta^{\prime} X\right)=F\left(\beta^{\prime} X\right)\right.\right.\right.$

Dengan memasukan variabel-variabel penelitian maka model yang digunakan adalah:

$$
\begin{aligned}
& P\left(Y_{1}=1\right)=\alpha+\beta_{1}(X 1)+\beta_{2}(X 2)+\varepsilon \\
& P\left(Y_{2}=1\right)=\alpha+\beta_{3}(X 1)+\beta_{4}(X 2)+\varepsilon \\
& P\left(Y_{2}=1\right)=\alpha+\beta_{5}(Y 1)+\varepsilon
\end{aligned}
$$

untuk melihat rasio keberhasilan atau Odds growing model tersebut ditransform dalam bentuk log natural

$$
\left(\frac{P}{1-P}\right)=e^{a} e^{\beta i X i}
$$

Sehingga menjadi:

$$
\begin{aligned}
P & =\exp \left\{\alpha+\beta_{i} X_{i} /\left(1+\exp \left(\alpha+\beta_{i} X_{i}\right)\right\}\right. \\
\exp & =e=2,71828 ; \frac{P}{1-P}=\text { odds ratio,; } X i=\text { variabel bebas }
\end{aligned}
$$

Odds ratio merupakan ukuran risiko atau kecenderungan untuk mengalami kejadian sukses antara satu kategori dengan kategori lainnya, didefinisikan sebagai ratio dari odds untuk $x j=1$ terhadap $x j=0$. Odds ratio ini menyatakan risiko atau kecenderungan pengaruh observasi dengan $\mathrm{xj}$ $=1$ adalah berapa kali lipat jika dibandingkan dengan observasi dengan $\mathrm{xj}=0$. Untuk variabel bebas yang berskala kontinu maka interpretasi dari koefisien $\beta \mathrm{j}$ pada model regresi logistik adalah setiap kenaikan c unit pada variabel bebas akan menyebabkan risiko terjadinya $\mathrm{Y}=1$, adalah $\exp (\mathrm{c} . \beta \mathrm{j})$ kali lebih besar.

\section{HASIL DAN PEMBAHASAN

\begin{tabular}{|c|c|c|c|}
\hline & & & kuensi \\
\hline & Keterangan & Jumlah & $\begin{array}{c}\text { Persentase } \\
(\%)\end{array}$ \\
\hline & DKI Jakarta & 3 & 4.11 \\
\hline & Jawa Barat & 24 & 32.87 \\
\hline & $\begin{array}{c}\text { Jawa } \\
\text { Tengah }\end{array}$ & 7 & 9.59 \\
\hline & Jawa Timur & 5 & 6.85 \\
\hline & Banten & 1 & 1.37 \\
\hline & $\begin{array}{l}\text { Kalimantan } \\
\text { Tengah }\end{array}$ & 1 & 1.37 \\
\hline & $\begin{array}{l}\text { Kalimantan } \\
\text { Selatan }\end{array}$ & 2 & 2.74 \\
\hline & $\begin{array}{l}\text { Kalimantan } \\
\text { Timur }\end{array}$ & 1 & 1.37 \\
\hline & $\begin{array}{c}\text { Sumatera } \\
\text { Utara }\end{array}$ & 2 & 2.74 \\
\hline Usaha & $\begin{array}{c}\text { Sumatera } \\
\text { Barat }\end{array}$ & 6 & 8.21 \\
\hline & $\begin{array}{c}\text { Sulawesi } \\
\text { Selatan }\end{array}$ & 4 & 5.48 \\
\hline & $\begin{array}{l}\text { Sulawesi } \\
\text { Tenggara }\end{array}$ & 1 & 1.37 \\
\hline & $\begin{array}{c}\text { Nusa } \\
\text { Tenggara } \\
\text { Barat } \\
\text { (NTB) }\end{array}$ & 2 & 2.74 \\
\hline & $\begin{array}{c}\text { Nusa } \\
\text { Tenggara } \\
\text { Timur } \\
\text { (NTT) }\end{array}$ & 2 & 2.74 \\
\hline & Bali & 5 & 6.85 \\
\hline & NAD & 5 & 6.85 \\
\hline & $\begin{array}{l}\text { Bangka } \\
\text { Belitung }\end{array}$ & 2 & 2.74 \\
\hline & DTAL & 73 & 100 \\
\hline
\end{tabular} \\ Deskripsi Responden Penelitian}

Responden dalam penelitian ini dapat diklasifikasikan sebagai berikut :

Tabel 1. Deskripsi Responden

Berdasarkan Lokasi Usaha

\section{Sumber: data diolah}

Jumlah responden dalam penelitian ini sebagian besar memiliki lokasi usaha organik di daerah Jawa Barat yaitu sebesar 24 responden (32.87\%).Dari berbagai data yang diperoleh ditemukan bahwa untuk produk organik lokal, masih banyak produk di pasaran yang tidak menggunakan logo Organik Indonesia, terutama di Bandung dan Yogyakarta.Tampaknya konsumen organik di Bandung dan Yogyakarta tidak 
mempermasalahkan sertifikasi organik. Perbandingan antara produk yang bersertifikat organik dan yang tidak bersertifikat masih cukup besar. Produk tidak bersertifikat masih ramai di pasar, terutama di wilayah Bogor (SPOI, 2014).

\section{Deskripsi Hasil Penelitian}

Analisis dan hasil penelitian dapat dideskripsikan sebagai berikut :

Tabel 2. Dependent Variable Encoding

\begin{tabular}{|l|r|}
\hline Original Value & Internal Value \\
\hline Tidak Tertarik & 0 \\
Tertarik & 1 \\
\hline
\end{tabular}

Sumber : data diolah

Tabel 2 diatas menunjukkan bahwa menurut pengkodean SPSS, yang termasuk kategori sukses dalam pemrosesan data adalah tertarik untuk memiliki sertifikasi organik. Pemberian kode pada variabel terikat terbagi menjadi dua kategori, yaitu kategori "Tidak Tertarik" dengan kode 0 dan "Tertarik" dengan kode 1. Oleh karena yang diberi kode 1 adalah "Tertarik", maka "Tertarik" menjadi referensi atau efek dari penyebab yang dihipotesiskan sebagai penyebab munculnya efek atau masalah. Dalam hal ini, "Tertarik" menjadi efek yang dapat meningkatkan preferensi petani untuk memiliki sertifikasi organik.

Tabel 3. Iteration History ${ }^{\mathrm{a}, \mathrm{b}, \mathrm{c}}$

\begin{tabular}{|lr|r|r|}
\hline \multirow{2}{*}{ Iteration } & & & Coefficients \\
\cline { 4 - 4 } & Step 0 & -2 Log likelihood & Constant \\
& 1 & 100,087 &, 247 \\
& 2 & 100,087 &, 248 \\
& 3 & 100,087 &, 248 \\
\hline
\end{tabular}

a. Constant is included in the model.

b. Initial -2 Log Likelihood: 100,087

c. Estimation terminated at iteration number 3 because parameter estimates changed by less than ,001.

Sumber: data diolah
Penilaian kesesuaian model penelitian terhadap data (overall fit model) dilakukan dengan menetapkan hipotesis sebagai berikut:

H0: Model yang dihipotesiskan tidak fit dengan data.

Ha: Model yang dihipotesiskan fit dengan data.

Tabel 3 menunjukkan bahwa pada block 0 atau ketika variabel bebas tidak dimasukkan dalam model, ditemukan nilai hitung -2 Log Likelihood sebesar 100,087 dan nilai Degree of Freedom (DF) $=\mathrm{N}-1=$ $73-1=72$. Berdasarkan tabel Chi-Square dengan nilai DF 72 dan Probabilitas 0.05 ditemukan nilai sebesar 92,808 . Nilai ini selanjutnya disebut sebagai nilai tabel. Hasil penelitian menunjukkan bahwa nilai hitung -2 Log Likelihood sebesar 100,087 adalah lebih besar dibandingkan nilai tabelnya yaitu sebesar 92,808 menunjukkan bahwa hasil penelitian menolak $\mathrm{H} 0$. Artinya, model penelitian sebelum memasukkan variabel bebas adalah TIDAK FIT dengan data.

Tabel 4. Classification Table ${ }^{a, b}$

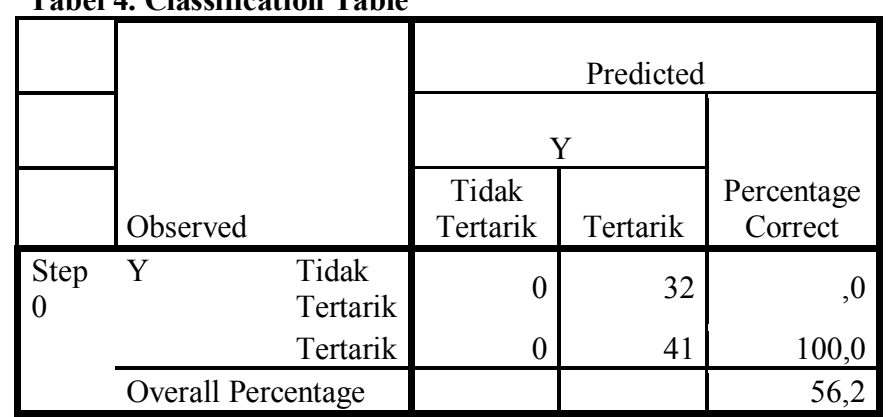

a. Constant is included in the model.

b. The cut value is , 500

Sumber: data diolah

Tabel 4 menunjukkan ketepatan model dalam mengklasifikasikan observasi adalah $56,1 \%$. Artinya dari 73 observasi terdapat 41 observasi yang tepat pengklasifikasiannya oleh model regresi logistik. Jumlah observasi yang tepat pengklasifikasiannya dapat dilihat pada diagonal utama. 
Tabel 5. Variables in the Equation

\begin{tabular}{|c|c|c|c|c|c|c|}
\hline & B & S.E. & Wald & Df & Sig. & $\begin{array}{l}\operatorname{Exp} \\
\text { (B) }\end{array}$ \\
\hline $\begin{array}{ll}\text { Step } & \text { Constant } \\
0 & \end{array}$ & 248 & ,236 & 1,104 & 1 & $\begin{array}{r}, 29 \\
3\end{array}$ & 1,281 \\
\hline
\end{tabular}

Sumber: data diolah

Tabel 5 merupakan hasil pengolahan data sebelum variabel independen dimasukkan ke dalam model. Sedangkan tabel 6 merupakan hasil pengolahan data setelah variabel bebas dimasukkan ke dalam model, yaitu variabel X1 dan X2 dan X3. Di mana $\mathrm{X} 1$ adalah variabel jangkauan pasar, $\mathrm{X} 2$ adalah variabel skala produksi, dan X3 adalah variabel panjang saluran pemasaran. Hasil penelitian menunjukkan bahwa sebelum variabel bebas dimasukkan ke dalam model, memiliki tingkat signifikansi yang tinggi yaitu 0,293 (lebih besar dari 0,05). Sedangkan data pada tabel 5.7 yaitu setelah variabel bebas dimasukkan ke dalam model menunjukkan tingkat sig. 0,000 (lebih kecil dari 0,05$)$ pada semua variabel bebasnya. Berdasarkan hasil diatas dapat diketahui bahwa terdapat tiga variabel bebas yang signifikan berpengaruh terhadap preferensi petani untuk memiliki sertifikasi organik.

Tabel 6. Variables not in the Equation

\begin{tabular}{|lll|r|r|r|}
\hline & & & Score & Df & Sig. \\
\hline Step & Variables & X1 & 34,829 & 1 &, 000 \\
0 & & & & \\
& & X2 & 27,672 & 1 &, 000 \\
& & X3 & 39,604 & 1 &, 000 \\
& \multicolumn{2}{|l}{ Overall Statistics } & 44,696 & 3 &, 000 \\
\hline
\end{tabular}

Sumber: data diolah

Tabel 7. Omnibus Tests of Model Coefficients

\begin{tabular}{|rl|r|r|r|}
\hline & & Chi-square & \multicolumn{1}{c|}{ df } & \multicolumn{1}{c|}{ Sig. } \\
\hline Step 1 & Step & 53,976 & 3 &, 000 \\
& Block & 53,976 & 3 &, 000 \\
& Model & 53,976 & 3 &, 000 \\
\hline
\end{tabular}

Sumber: data diolah

Tabel 7 menunjukkan bahwa nilai signifikansi model adalah sebesar 0,000 .
Karena nilai signifikansinya lebih kecil dari 0,05 maka dapat disimpulkan bahwa ketiga variabel bebas dalam penelitian ini secara bersama-sama berpengaruh terhadap preferensi petani untuk memiliki sertifikasi organik.

Tabel 8. Model Summary

\begin{tabular}{|l|r|r|r|}
\hline Step & $\begin{array}{c}-2 \text { Log } \\
\text { likelihood }\end{array}$ & $\begin{array}{c}\text { Cox \& Snell } \\
\text { R Square }\end{array}$ & $\begin{array}{c}\text { Nagelkerke R } \\
\text { Square }\end{array}$ \\
\hline 1 & $46,111^{\mathrm{a}}$ &, 523 &, 700 \\
\hline
\end{tabular}

a. Estimation terminated at iteration number 6 because parameter estimates changed by less than ,001.

Sumber: data diolah

Cox \& Snell R Square merupakan ukuran yang mencoba meniru ukuran R2 pada tehnik regresi yang didasarkan pada teknik estimasi likelihood dengan nilai maksimum kurang dari satu sehingga sulit diintepretasikan. Sedangkan Nagelkerke R Square merupakan modifikasi dari koefisien Cox \& Snell R Square untuk memastikan bahwa nilai pengaruhnya bervariasi dari angka 0 sampai 1 . Tabel 8 menunjukkan bahwa nilai Nagelkerke $\mathrm{R}$ Square dalam penelitian ini adalah sebesar 0,700. Artinya, variabel terikat dalam penelitian ini dapat dijelaskan oleh variabel bebasnya sebesar $70 \%$ sedangkan sisanya sebesar $30 \%$ dijelaskan oleh variabel bebas lain di luar penelitian ini.

Berdasarkan dari hasil penelitian tersebut menunjukkan bahwa preferensi petani untuk memiliki sertifikasi organik dipengaruhi oleh ketiga variabel bebas yang diteliti, yaitu jangkauan pasar, skala produksi, dan panjang saluran pemasaran. Hasil penelitian ini didukung oleh data dari Aliansi Organis Indonesia (Sertifikasi Organik Komunitas, 2013) yang menunjukkan bahwa khususnya di Indonesia, sistem penjaminan pihak ketiga (sertifikasi organik) umumnya diadopsi oleh produsen yang memenuhi kriteria sebagai berikut : 
a) Memiliki skala lahan dan/atau volume produksi yang tergolong besar (angka tepatnya tergantung dari jenis komoditas yang diusahakan);

b) Produk yang dihasilkan utamanya dijual untuk pasar internasional atau ekspor (meski tidak tertutup kemungkinan produk tersebut juga dijual ke pasar domestik, utamanya melalui jaringan retail besar seperti supermarket);

c) Konsumen yang membeli produk mereka berada jauh (secara geografis dari lokasi produsen).

Sertifikasi biasanya diadopsi oleh petani berskala tergolong besar (angka tepatnya tergantung dari jenis komoditas yang diusahakan). Hal ini dikarenakan biaya sertifikasi organik dianggap cukup mahal bagi petani berskala kecil, yaitu antara $R p$. 7.500.000,00 sampai dengan Rp. 15.000.000,00 tergantung dari jarak antara lokasi lahan petani dengan LSO (Lembaga Sertifikasi Organik). Untuk produk yang memiliki volume produksi yang besar, biaya sertifikasi tidak akan terlalu berpengaruh terhadap harga produk yang dihasilkan. Tetapi untuk pertanian dengan skala kecil, biaya tersebut akan berpengaruh besar terhadap harga jual produknya (economic of scale).

Bagi produk organik dengan skala pemasaran yang bersifat lokal, sertifikasi organik tidak terlalu dibutuhkan oleh petani. Pada pemasaran bersifat lokal, konsumen biasanya mengetahui adanya produk berdasarkan rekomendasi dari mulut ke mulut. Konsumen juga seringkali mendatangi langsung produsen untuk memastikan "keorganikan" produk. Kepercayaan konsumen akan keorganikan produk organik tidak didasarkan pada label organik, tetapi lebih kepada kepercayaan kepada produsennya secara langsung. Hal seperti ini bisa dilakukan apabila pemasaran produk dilakukan tanpa perantara.

Penelitian yang dilakukan oleh Gerrard et al. (2013) pada konsumen organik di
Inggris menemukan bahwa konsumen organik menganggap bahwa adanya label sertifikasi akan meningkatkan kepercayaan konsumen terhadap produk organik. Hasil yang sama juga terjadi pada penelitian yang dilakukan oleh Nelson et al. (2010) pada konsumen organik di Mexico yang menunjukkan bahwa sertifikasi pada produk organik akan meningkatkan keinginan konsumen untuk membeli produk organik.

Berbeda dengan penelitian tentang konsumen organik di Eropa dan Amerika, penelitian tentang konsumen organik di Jepang menunjukkan hasil yang sangat berbeda. Produsen dan konsumen organik di Jepang lebih menyukai menggunakan cara "teikei" (partnership) sejak tahun 1971 dalam memasarkan produk organiknya. Dalam hal ini pembelian konsumen lebih didasarkan pada kepercayaan konsumen kepada petani penanam produk, bukan kepada sertifikasi yang tertera di produk (Giner, 2009).

Konsumen organik di Jepang juga menggunakan "sanchoku" (direct marketing) yang dimulai pada tahun 1980 dimana produsen, retailer, restoran dan konsumen kesemuanya berhubungan secara langsung dan bekerjasama dalam menentukan keragaman, jumlah dan harga produk organik (Kimura dan Nishiyama, 2008). Pada konsumen organik di Jepang, pembelian pada produk organik tidak didasarkan pada label sertifikasi produk tetapi lebih kepada kepercayaan yang terjalin diantara produsen, konsumen, dan semua pihak yang terlibat dalam pembelian produk.

Berdasarkan perbedaan hasil penelitian tersebut, dapat disimpulkan bahwa bagi petani berskala kecil, tanpa perantara perdagangan, dan memiliki pemasaran yang bersifat lokal, merasa tidak tertarik untuk memiliki sertifikasi organik karena konsumen menganggap sertifikasi organik dapat meningkatkan biaya produksi sehingga harga jual menjadi lebih tinggi. Kepercayaan konsumen atas keorganikan produk 
didasarkan pada kepercayaan hubungan diantara produsen-konsumen.

Karakteristik konsumen organik di Indonesia dianggap mirip dengan karakteristik konsumen organik di Jepang. Sebagai sesama masyarakat Asia, keduanya memiliki sifat kolektif. Berbeda dengan masyarakat di Eropa yang lebih bersifat individualistis. Pada masyarakat yang bersifat kolektif, biasanya lebih mendasarkan kepercayaan akan produk pada keeratan hubungan. Berbeda dengan masyarakat yang bersifat individual, mereka lebih percaya kepada hal-hal yang bersifat riil (terlihat).

\section{SIMPULAN DAN SARAN}

\section{Simpulan}

Simpulan yang diperoleh dari hasil penelitian yang telah dilakukan menunjukkan bahwa model penelitian telah dinyatakan FIT. Sehingga dapat disimpulkan bahwa preferensi petani untuk memiliki sertifikasi organik dipengaruhi oleh jangkauan pasar, skala produksi, dan panjang saluran pemasaran.

\section{Saran}

Saran yang dapat direkomendasikan oleh peneliti terkait dengan pembahasan awal dalam penelitian ini adalah sebagai berikut :

1. Perlu diadakan penelitian lebih lanjut mengenai sertifikasi organik khusus bagi petani berskala kecil. Sebagian besar petani kecil tidak tertarik untuk memiliki sertifikasi organik karena biayanya yang cukup tinggi. Tetapi dengan diberlakukannya Peraturan Menteri Pertanian

No.64/Permentan/OT.140/5/2013 tentang Sistem Pertanian Organik dimana semua produk organik yang beredar di Indonesia baik produksi dalam negeri maupun impor harus mencantumkan logo organik Indonesia, menjadi suatu fenomena yang sangat menarik untuk diteliti tentang bagaimana petani organik berskala kecil menghadapi tantangan tersebut.

2. Memperkuat jaringan dan kerjasama antara petani dan pengusaha, petani dengan Pemerintah dan Lembaga Swadaya Masyarakat dengan petani. Hubungan ini akan sangat membantu perkembangan pertanian organik.

3. Pola pikir petani yang masih pragmatis terhadap pertanian organik perlu segera diperbaiki dengan meningkatkan frekuensi penyuluhan pertanian organik yang lebih intensif.

4. Publikasi penelitian tentang pertanian organik hendaknya lebih diperbanyak lagi di kalangan Pemerintah, Lembaga Swadaya Masyarakat bahkan petani sebagai pedoman atau bahan sosialisasi pertanian organik kepada masyarakat.

\section{DAFTAR PUSTAKA}

Badgley, C, J. Moghtader, E. Quitero, E. Zakem, M.J Chppell, K. AvilesVazquez, A. Samulon and I. Perfercto, 2007, Organic agriculture and the global food supply, Renewable Agriculture and Food Systems, Vol. 22, No. 2, p. 86-108.

Chen, Mei-Fiang, 2009, Attitude toward organic foods among Taiwanese as related to health consciousness, environmental attitudes, and the mediating effects of a healthy lifestyle, British Food Journal, Vol. 111, No. 2, p. 165-78.

Essoussi, Leila Hamzaoui, and Zahaf, Mehdi, 2008, Decision making process of community organic food consumers : an exploratory study, Journal of Consumer Marketing, Vol. 25, No. 2, p. 95-104.

Gerrard, Catherine, Mieke Janssen, Laurence Smith, Ulrich Hamm and Susanne Padel, 2013, UK consumer reactions to organic certification logos, British 
Food Journal, Vol. 115, No. 5, p. 72742.

Khudori, 2014, Masa Depan Pertanian Organik di Indonesia, Organis, Edisi 33 (Januari - Maret), Bogor : Aliansi Organis Indonesia.

Larceneux, Fabrice; Benoit-Moreau, Florence and Renaudin, Valerie, 2012, Why might organic labels fail to influence consumer choices? Marginal labeling and brand equity effects, Journal Consum Policy, Vol. 35, p. 85-104.

Paul, Justin, and Rana, Jyoti, 2012, Consumer behavior and purchase intention for organic food, Journal of Consumer Marketing, Vol. 29, No. 6, p. 412-22.

Radman, Marija, 2005, Consumer consumption and perception of organic products in Croatia, British Food Journal, Vol. 107, No. 4, p. 263-73.

Smed, Sinne, Andersen, Laura N., Kaergard, Niels and Daugbjerg, Carsten, 2013, A matter of trust : how trust influence organic consumption, Journal of Agricultural Science, Vol. 5, No. 7, p. 91-106.

Sulaeman, Ahmad (2014), Mengapa Pilih Organik? Edisi 36 (OktoberDesember 2014), hal 5-7.

Statistik Pertanian Organik Indonesia, 2014, Bogor : Aliansi Organis Indonesia.

Tarkiainen, Anssi and Sundqvist, 2005, Subjective norms, attitudes and intentions of Finnish consumers in buying organic food, British Food Journal, Vol. 107, No. 11, p. 808-12.

Truong, Thien T., Yap, Matthew H.T., and Ineson, Elizabeth M, 2012, Potential Vietnamese consumers' perceptions of organic foods, British Food Journal, Vol. 114, No.4, p. 529-43. 